\title{
Rozmiary i regionalne zróżnicowanie polskiego rynku nieruchomości rolnych
}

\section{Wstęp}

Rynek nieruchomości jako sektorowy segment rynku, wyodrębniony ze względu na specyficzne, właściwe tylko jemu cechy strukturalne i funkcjonalne, w literaturze przedmiotu nie jest jednolicie definiowany. Wśród licznych definicji, prezentowanych przez różnych autorów, uwagę zwraca ujęcie systemowe, traktujące rynek nieruchomości jako system, złożony z powiązanych ze sobą różnymi relacjami podsystemów [Bryx 2006]. System ten to układ dynamiczny, którego funkcjonowanie jest wypadkową oddziaływania czynników ekonomicznych, politycznych, prawnych i społecznych [Kucharska-Stasiak 2006] oraz silnych wpływów instytucjonalnych [Załęczna 2010]. Wymienione czynniki, postrzegane zarówno w kategorii warunków sprzyjających rozwojowi tego rynku, jak i barier jego rozwoju [Kucharska-Stasiak 2001], tworzą tzw. otoczenie rynku. Szeroko rozumiane otoczenie w połączeniu z cechami nieruchomości - ich lokalizacją, typem i rodzajem praw na nich ustanowionych, to podstawowe obszary, w których upatruje się źródeł ryzyka na rynku nieruchomości [Siemińska 2006].

Rozważając potencjalne kierunki inwestowania na rynku nieruchomości, należy zwrócić uwagę na stosowany powszechnie dla potrzeb analitycznych podział tego rynku na segmenty, uwzględniający funkcje i przeznaczenie użytkowe nieruchomości. Wyodrębniony na jego podstawie rynek nieruchomości rolnych ${ }^{1}$,

\footnotetext{
${ }^{1}$ Nieruchomości rolne to nieruchomości gruntowe kwalifikowane jako rolne, gdy z jednej strony spełniają kryterium wymienione w art. 46 kodeksu cywilnego, $\mathrm{z}$ drugiej zaś nie zostały - jak wynika $\mathrm{z}$ art. 2 pkt 1 ustawy o kształtowaniu ustroju rolnego - przeznaczone w miejscowych planach zagospodarowania przestrzennego na cele inne niż rolne [Truszkiewicz 2017].
} 
podobnie jak inne segmenty rynku nieruchomości, obejmuje swoją strukturą funkcjonalno-organizacyjna podmioty i instytucje rynkowe oraz przedmioty obrotu, czyli nieruchomości. Ze względu na brak wykładni normatywnej, pojęcie obrotu nieruchomościami rolnymi nie jest jednolicie interpretowane. W szerokim ujęciu (sensu largo) obejmuje ono wszystkie formy przeniesienia praw do korzystania z nieruchomości. W ujęciu wąskim (sensu stricto) odnosi się natomiast wyłącznie do zmian własnościowych dokonywanych $\mathrm{w}$ drodze czynności cywilnoprawnych [Czechowski 2015]. Prawo własności, będące podstawowym elementem prawidłowego funkcjonowania rynku [Bryx 2000], w przypadku nieruchomości rolnych może być przenoszone na podstawie przepisów kodeksu cywilnego, lub uregulowań szczególnych. Do najczęściej zawieranych umów w obrocie tego typu nieruchomościami, poza umową sprzedaży i umową darowizny, zaliczyć należy umowę dożywocia oraz umowę przekazania gospodarstwa rolnego w zamian za rentę lub emeryturę [Czechowski 2015].

Nieruchomości rolne zaliczane do tzw. nieruchomości niezurbanizowanych [Hopfer 1997, Cymerman 2011] kojarzone są one głównie z obszarami wiejskimi, choć zlokalizowane są również w granicach administracyjnych miast [Belniak i Uchman 2001]. Te ostatnie pełnią jednak inne funkcje, będąc istotnym składnikiem systemu przyrodniczego obszarów miejskich. Tylko ich część wykorzystywana jest do prowadzenia działalności rolniczej, podczas gdy duży odsetek stanowią odłogi i ugory [Krzyk i in. 2013]. Grunty rolne będące użytkami rolnymi w miastach, po nowelizacji ustawy o ochronie gruntów rolnych i leśnych ${ }^{2}$ stały się bardzo atrakcyjne dla inwestorów w związku ze zniesieniem wymogu uzyskania zgody ministra właściwego do spraw rolnictwa i rozwoju wsi na zmianę przeznaczenia oraz wnoszenia należności i opłat $\mathrm{z}$ tytutu ich wyłączenia z produkcji.

\section{Metodyka badań}

Celem artykułu jest określenie uwarunkowań, skali oraz struktury obrotu nieruchomościami rolnymi w Polsce. Dla potrzeb jego realizacji wykorzystano w szczególności dane sprawozdawczości notarialnej udostępniane przez Ministerstwo Sprawiedliwości, które od 1990 roku publikuje Instytut Rozwoju Miast ${ }^{3}$. Umożliwiły one ukazanie zmian w liczbie i strukturze transakcji w skali

\footnotetext{
${ }^{2}$ Zmiany wprowadzone ustawą z dnia 19 grudnia 2008 roku o zmianie ustawy o ochronie gruntów rolnych i leśnych, Dz.U. nr 237, poz. 1657.

${ }^{3}$ Od początku okresu transformacji Instytut Rozwoju Miast (wcześniej Instytut Gospodarki Mieszkaniowej) publikuje „Monitoring polskiego rynku nieruchomości” w układzie rzeczowej i regionalnej klasyfikacji zawartych transakcji [Kałkowski i Rydzik 2008].
} 
kraju i poszczególnych województw z uwzględnieniem ich podziału na rynkowe i nierynkowe. Zwrócono również uwagę na obrót nieruchomościami rolnymi z udziałem cudzoziemców i regionalne zróżnicowanie skali tego zjawiska na podstawie sprawozdawczości Ministerstwa Spraw Wewnętrznych i Administracji.

Zakres czasowy opracowania obejmuje zasadniczo lata 2004-2013, przy czym dla potrzeb prowadzonych analiz porównawczych, wykorzystano zarówno okres poprzedzający, jak i lata późniejsze, biorąc pod uwagę dostępność danych oraz możliwości ich pozyskania z różnych źródeł.

\section{Ogólne tendencje na polskim rynku nieruchomości rolnych w warunkach gospodarki rynkowej}

Polski rynek nieruchomości w warunkach gospodarki rynkowej ma za sobą okresy przekształceń, wyznaczających kolejne fazy jego rozwoju. Jedną z charakterystycznych cech pierwszej z nich, przypadającej na lata 1989-1992, były dynamiczne zmiany regulacji prawnych [Kucharska-Stasiak 2001]. Dla funkcjonowania rynku nieruchomości rolnych szczególne znaczenie ma wejście w życie nowelizacji ustawy kodeks cywilny z 28 lipca 1990 roku ${ }^{4}$, która zniosła praktycznie wszelkie istniejące wcześniej ograniczenia w obrocie tego typu nieruchomościami. Dotyczyło to norm obszarowych, zasad podziału i dziedziczenia gospodarstw oraz zakupu gruntów państwowych [Ostrowski 1996].

Efekty liberalizacji obrotu nieruchomościami rolnymi zaczęły się uwidaczniać po 1992 roku w związku z realizacją transakcji wcześniej ,zatrzymanych” ze względu na niekorzystne przepisy emerytalne [Ostrowski 1998], co przekładało się głównie na skalę obrotu pozarynkowego. Na zwiększenie liczby realizowanych transakcji rynkowych korzystny wpływ miały warunki nabywania gruntów Zasobu Własności Rolnej Skarbu Państwa, co wiązało się z możliwością zwolnienia na okres 5 lat z podatku rolnego przy ich zakupie, niezależnie od nabytej powierzchni. Po 1996 roku, w którym zanotowano rekordową sprzedaż tego rodzaju gruntów (193 tys. ha), przepisy nie były już tak korzystne dla nabywców w związku z wprowadzeniem kryterium obszarowego (100 ha), powyżej którego wspomniane preferencje nie miały zastosowania [Woś 2007]. Okres bezpośrednio poprzedzający integrację Polski z Unią Europejską cechowała stagnacja na rynku nieruchomości rolnych. Niewielkie ożywienie wystapiło okresowo po zapowiedziach wprowadzenia ustawy o kształtowaniu ustroju rolnego, ponieważ znajomość nowych regulacji w powiązaniu z przewidywanym wzrostem cen zie-

\footnotetext{
${ }^{4}$ Weszła w życie 1 października 1990 roku.
} 
mi rolnej oraz spodziewanymi korzyściami z jej posiadania w okresie poakcesyjnym, dopingowały do finalizowania planowanych transakcji (rys. 1).

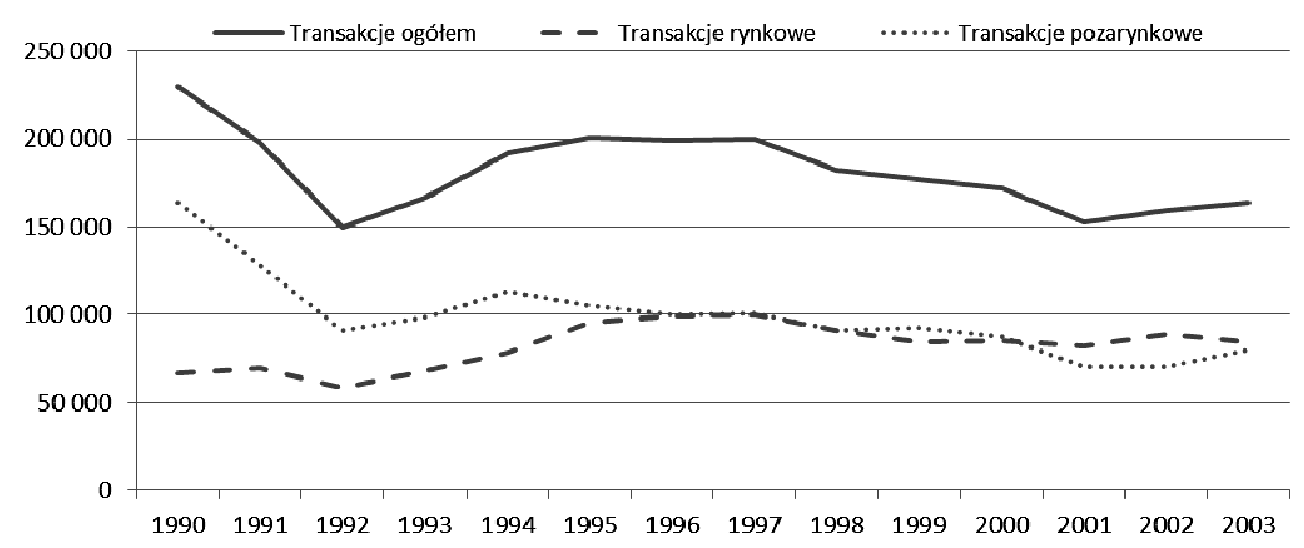

\section{Rysunek 1}

Obrót nieruchomościami rolnymi w Polsce w latach 1990-2003

Źródło: Opracowanie własne na podstawie Kałkowski [ 2011].

Ograniczenia w obrocie nieruchomościami rolnymi, które weszły w życie 16 lipca 2003 roku, szczególnie w początkowym okresie ich funkcjonowania budziły wiele kontrowersji i negatywnych ocen. Zwracano uwagę m.in. na to, że przepisy ustawy o kształtowaniu ustroju rolnego są niesprecyzowane oraz zawierają wiele nieostrych i niedookreślonych wyrażeń [Czerwińska-Koral 2016]. Ustawa niewątpliwie skomplikowała obrót nieruchomościami rolnymi, co wiązało się z możliwością korzystania przez Agencję Nieruchomości Rolnych $\mathrm{z}$ uprawnień $\mathrm{w}$ postaci prawa pierwokupu i prawa nabycia. Związane $\mathrm{z}$ tym monitorowanie rynku nieruchomości rolnych, napotykało bowiem trudności w postaci braku określenia $w$ ustawie limitu powierzchni poniżej którego nie stosuje się jej przepisów oraz problemów z ustalaniem przeznaczenia nieruchomości objętych transakcjami w związku z wygaśnięciem planów zagospodarowania przestrzennego w wielu gminach [Klank 2006].

Wpływ integracji z Unią Europejską oraz objęcie polskiego rolnictwa wspólną polityką rolną, zaczęły się uwidaczniać w zasadzie po 2005 roku, czego wyrazem jest ożywienie obrotu gruntami rolnymi oraz systematyczny wzrost ich cen transakcyjnych, którego nie zakłóciły nawet zawirowania związane z globalnym kryzysem gospodarczym [Żelazowski 2014]. Tendencje i kierunki zmian cen sprzedaży gruntów państwowych były przy tym zbieżne z notowanymi na rynku prywatnym.

Dynamiczny wzrost cen nieruchomości rolnych to niewątpliwie najbardziej widoczny efekt integracji z Unią Europejską. Innym charakterystycznym zjawi- 
skiem jest wzrost znaczenia obrotu rynkowego tego rodzaju nieruchomościami, mający odzwierciedlenie $\mathrm{w}$ trwałej zmianie struktury realizowanych transakcji (rys. 2). Tego typu zmiana jakościowa jest korzystna m.in. z punktu widzenia rozwoju polskiego sektora rolnego. $Z$ analiz prowadzonych przez Instytut Ekonomiki Rolnictwa i Gospodarki Żywnościowej wynika bowiem, że obrót o charakterze rynkowym sprzyja procesowi koncentracji gruntów, z kolei przepływy rodzinne, jako forma obrotu nierynkowego, skutkują stagnacją w zakresie struktury agrarnej [Kowalski 2015]. Z zapisów notarialnych dotyczących przenoszenia własności nieruchomości rolnych wynika, że w latach 2004-2013 transakcje rynkowe stanowiły $54,7 \%$. W analogicznym okresie w latach $1994-2003$ było to odpowiednio o 5,4 p.p. mniej (tab. 1). Należy przy tym zaznaczyć, że w porównaniu do lat 1994-2003 zrealizowano łącznie o ponad 234 tys. mniej transakcji nieruchomościami rolnymi, co w głównej mierze wynika $\mathrm{z}$ dużej aktywności transakcyjnej na analizowanym rynku w latach 1995-1997. Z 26,9 do 25,4\% zmniejszył się również udział transakcji tego rodzaju nieruchomościami w transakcjach nieruchomościami ogółem. Dla porównania w 1990 roku kształtował się on na poziomie ponad 51\% [Kałkowski 2011].

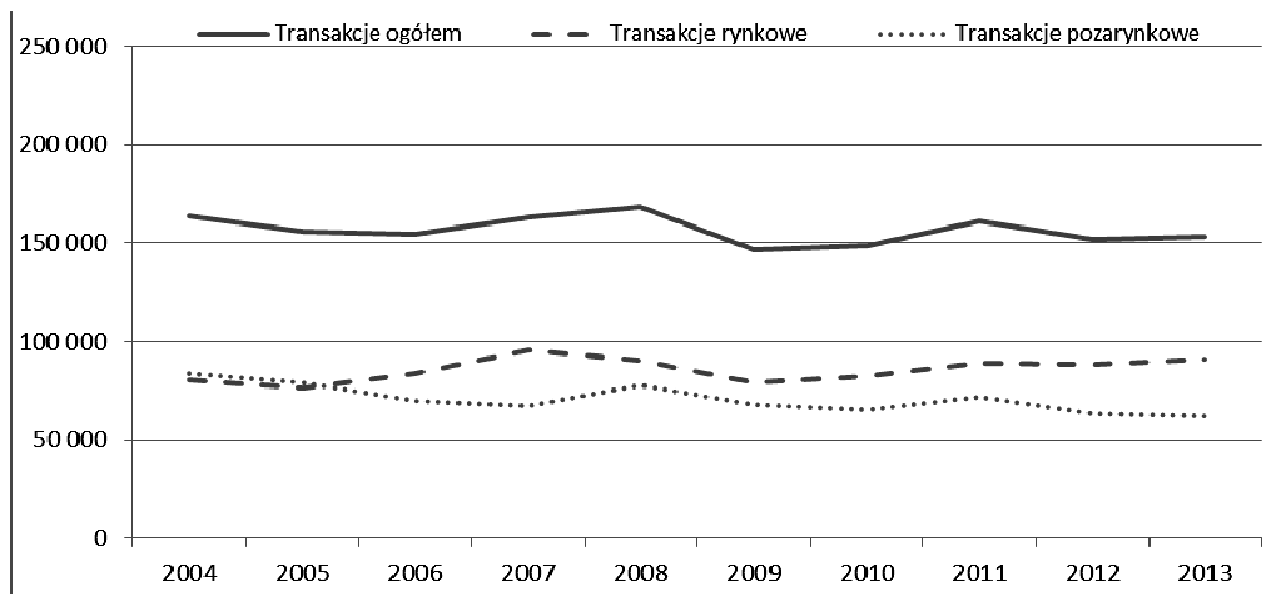

Rysunek 2

Obrót nieruchomościami rolnymi w Polsce w latach 2004-2013

Źródło: Opracowanie własne na podstawie Kałkowski [2011, 2015].

\section{Regionalne zróżnicowanie liczby i struktury transakcji nieruchomościami rolnymi}

Pojęcie rynku nieruchomości jest ściśle związane z jego wymiarem przestrzennym, przejawiającym się nie tylko zasięgiem geograficznym, w którego granicach zlokalizowane są nieruchomości tworzące ten rynek, ale także prze- 
strzennym zasięgiem podaży, popytu i cen danego typu nieruchomości [Cellmer 1999]. W zależności od wielkości obszaru objętego badaniem wyróżnić można rynek krajowy, jako obszar podstawowy, oraz mniejsze rynki regionalne i lokalne. W niniejszym opracowaniu dla potrzeb określenia uwarunkowań i skali zróżnicowania rynku wykorzystano administracyjny podział kraju, wyodrębniając $w$ ten sposób 16 rynków wojewódzkich, które poddano następnie analizie w zakresie wybranych cech.

\section{Tabela 1}

Polski rynek nieruchomości rolnych według województw - analiza porównawcza dla lat 1994-2003 i $2004-2013$

\begin{tabular}{|c|c|c|c|c|c|c|c|c|}
\hline \multirow{3}{*}{ Województwa } & \multicolumn{4}{|c|}{$\begin{array}{l}\text { Transakcje nieruchomościami } \\
\text { rolnymi }\end{array}$} & \multicolumn{4}{|c|}{$\begin{array}{c}\text { Udział transakcji } \\
\text { nieruchomościami rolnymi }\end{array}$} \\
\hline & \multicolumn{2}{|c|}{ razem } & \multicolumn{2}{|c|}{$\begin{array}{c}\text { w tym rynkowe } \\
{[\%]}\end{array}$} & \multicolumn{2}{|c|}{$\begin{array}{c}\text { w transakcjach } \\
\text { nieruchomo- } \\
\text { ściami ogółem } \\
{[\%]}\end{array}$} & \multicolumn{2}{|c|}{$\begin{array}{l}\text { w transakcjach } \\
\text { nieruchomościam } \\
\text { rolnymi ogółem } \\
{[\text { Polska = 100] }}\end{array}$} \\
\hline & $\begin{array}{l}1994- \\
-2003\end{array}$ & $\begin{array}{l}2004- \\
-2013\end{array}$ & $\begin{array}{l}1994- \\
-2003\end{array}$ & $\begin{array}{l}2004- \\
-2013\end{array}$ & $\begin{array}{l}1994- \\
-2003\end{array}$ & $\begin{array}{l}2004- \\
-2013\end{array}$ & $\begin{array}{l}1994- \\
-2003\end{array}$ & $\begin{array}{l}2004- \\
-2013\end{array}$ \\
\hline Dolnośląskie & 93087 & 69211 & 66,3 & 65,5 & 18,8 & 12,9 & 5,2 & 4,4 \\
\hline $\begin{array}{l}\text { Kujawsko- } \\
\text {-pomorskie }\end{array}$ & 82528 & 71801 & 61,0 & 60,9 & 27,1 & 24,3 & 4,6 & 4,6 \\
\hline Lubelskie & 258283 & 208653 & 50,4 & 53,9 & 56,3 & 52,9 & 14,4 & 13,3 \\
\hline Lubuskie & 28722 & 31882 & 71,3 & 75,6 & 15,8 & 23,6 & 1,6 & 2,0 \\
\hline Łódzkie & 123532 & 110170 & 44,2 & 52,0 & 31,1 & 28,5 & 6,9 & 7,0 \\
\hline Małopolskie & 155038 & 143096 & 31,4 & 46,0 & 29,6 & 25,1 & 8,6 & 9,2 \\
\hline Mazowieckie & 256003 & 211246 & 46,4 & 51,6 & 33,2 & 23,2 & 14,2 & 13,5 \\
\hline Opolskie & 47592 & 44421 & 59,2 & 63,6 & 24,8 & 25,4 & 2,6 & 2,8 \\
\hline Podkarpackie & 166384 & 156439 & 36,3 & 45.2 & 46,0 & 46,1 & 9,2 & 10,0 \\
\hline Podlaskie & 108219 & 84200 & 50,2 & 50,6 & 49,3 & 44,6 & 6,0 & 5,4 \\
\hline Pomorskie & 61226 & 58048 & 66,3 & 66,6 & 17,6 & 15,9 & 3,4 & 3,7 \\
\hline Śląskie & 69276 & 48007 & 32,5 & 48,7 & 13,5 & 7,9 & 3,8 & 3,1 \\
\hline Świętokrzyskie & 93314 & 99884 & 40,4 & 45,9 & 46,5 & 48,5 & 5,2 & 6,4 \\
\hline $\begin{array}{l}\text { Warmińsko- } \\
\text {-mazurskie }\end{array}$ & 72810 & 60857 & 66,1 & 71.5 & 29,6 & 24,1 & 4,0 & 3,9 \\
\hline Wielkopolskie & 119775 & 106000 & 56,4 & 57,8 & 24,3 & 21,1 & 6,7 & 6,8 \\
\hline $\begin{array}{l}\text { Zachodniopo- } \\
\text { morskie }\end{array}$ & 64089 & 61411 & 71,5 & 73,5 & 18,4 & 20,4 & 3,6 & 3,9 \\
\hline Polska ogółem & $\begin{array}{c}1799 \\
872 \\
\end{array}$ & $\begin{array}{l}1565 \\
326\end{array}$ & 49,5 & 54,7 & 27,0 & 25,4 & 100,0 & 100,0 \\
\hline
\end{tabular}

Żródło: Opracowanie własne na podstawie Kałkowski [2011, 2015]. 
Dane przedstawione w tabeli 1 dotyczace lat 2004-2013 wskazują na istotne zróżnicowanie poszczególnych rynków wojewódzkich w zakresie liczby realizowanych transakcji nieruchomościami rolnymi. Należy przy tym zaznaczyć, że w porównaniu $\mathrm{z}$ analogicznym okresem lat 1994-2003, nie nastąpiły istotne zmiany w ich strukturze przestrzennej. Niezmiennie rynki pięciu województw (mazowieckiego, lubelskiego, podkarpackiego, małopolskiego i łódzkiego) reprezentowały łącznie ponad połowę rynku krajowego. Dla porównania udział pięciu najmniej aktywnych rynków (lubuskie, opolskie, śląskie, pomorskie i zachodniopomorskie) nie przekraczał $16 \%$.

W latach 2004-2013 przeprowadzono łącznie ponad 850 tys. rynkowych transakcji dotyczących nieruchomości rolnych, przy czym zdecydowanie największą ich część $(81,9 \%)$ stanowiła sprzedaż realizowana przez podmioty prywatne (tab. 2). Obrót $\mathrm{z}$ ich udziałem dominował w przypadku wszystkich województw, mieszcząc się w przedziale od $51,7 \%$ w przypadku województwa lubuskiego do $95,5 \% \mathrm{w}$ województwie małopolskim. Najwięcej tego typu transakcji w ujęciu ilościowym zrealizowano w analizowanym okresie na terenie województwa lubelskiego, a najmniej w województwie śląskim. Udział tych województw w transakcjach realizowanych w skali kraju wynosił odpowiednio 13,1 i $2,7 \%$.

Duży udział obrotu prywatnego w strukturze rynkowych transakcji nieruchomościami wiązać należy ze strukturą własności gruntów w Polsce, wskazującą na dominację osób fizycznych, w których rękach pozostaje 57,8\% powierzchni ogólnej kraju. Na drugim miejscu jest Skarb Państwa (33,9\%), a na trzecim jednostki samorządu terytorialnego z zaledwie 4\% udziałem [Przewię́likowska 2016]. Przewaga własności prywatnej widoczna jest w jeszcze większym stopniu w użytkach rolnych, w przypadku których do osób fizycznych należy 75\% powierzchni gruntów zaliczanych do tej kategorii (66\% powierzchni w miastach). Skarb Państwa jest właścicielem zaledwie 19\% (15\% w miastach), a samorządy terytorialne skupiają w swoich rękach $2 \%$ tego typu gruntów w skali kraju i 13\% w miastach.

Zasoby użytków rolnych, uwzględniając podział administracyjny kraju, nie są rozmieszczone równomiernie. Największym potencjałem, mierzonym ich udziałem w powierzchni geodezyjnej, charakteryzują się województwa łódzkie, lubelskie i mazowieckie. Bliskie średniej krajowej są województwa dolnośląskie, małopolskie i podlaskie, a znacznie poniżej jej poziomu plasuje się województwo lubuskie [Klusek 2014].

W latach 2004-2013 udział Skarbu Państwa i gmin w ogólnej liczbie transakcji sprzedaży nieruchomości rolnych kształtował się na poziomie $18,1 \%$, co w porównaniu do lat 1994-2003 oznacza spadek o 2,3 p.p. Najwięcej tego typu 
transakcji realizowano na terenie województw podkarpackiego, warmińsko-mazurskiego i zachodniopomorskiego (tab. 2).

Powierzchnia gruntów rolnych posiadanych przez Skarb Państwa stale się zmniejsza, czego najważniejszą przyczyną jest zbywanie gruntów wchodzących w skład Zasobu Własności Rolnej Skarbu Państwa, którego wielkość w latach 2001-2014 zmniejszyła się o ponad połowę [Przewięźlikowska 2016]. Przepisy wprowadzone ustawą z dnia 14 kwietnia 2016 roku o wstrzymaniu sprzedaży nieruchomości Zasobu Własności Rolnej Skarbu Państwa oraz zmianie niektórych ustaw $^{5}$ zmieniły priorytety w zakresie gospodarowania gruntami Zasobu, przenosząc punkt ciężkości na ich wydzierżawianie. W efekcie powierzchnia grun-

\section{Tabela 2}

Polski rynek nieruchomości rolnych według województw - transakcje rynkowe (dane skumulowane za lata 2004-2013)

\begin{tabular}{|c|c|c|c|c|c|c|}
\hline \multirow{4}{*}{ Województwa } & \multicolumn{6}{|c|}{ Transakcje rynkowe } \\
\hline & \multicolumn{2}{|c|}{ razem } & \multicolumn{4}{|c|}{ w tym sprzedaż przez } \\
\hline & \multirow[t]{2}{*}{ liczba } & \multirow{2}{*}{$\begin{array}{c}{[\%]} \\
(\text { Polska }= \\
100)\end{array}$} & \multicolumn{2}{|c|}{$\begin{array}{c}\text { Skarb Państwa lub } \\
\text { gminę }\end{array}$} & \multicolumn{2}{|c|}{ inne osoby } \\
\hline & & & liczba & $\%$ & liczba & $\%$ \\
\hline Dolnośląskie & 45352 & 5,3 & 12672 & 27,9 & 32680 & 72,1 \\
\hline Kujawsko-pomorskie & 43704 & 5,1 & 5023 & 11,5 & 38681 & 88,5 \\
\hline Lubelskie & 112554 & 13,1 & 13506 & 12,0 & 99048 & 88,0 \\
\hline Lubuskie & 24115 & 2,8 & 11642 & 48,3 & 12473 & 51,7 \\
\hline Łódzkie & 57316 & 6,7 & 7975 & 13,9 & 49341 & 86,1 \\
\hline Małopolskie & 65766 & 7,7 & 2959 & 4,5 & 62807 & 95,5 \\
\hline Mazowieckie & 108908 & 12,7 & 8970 & 8,2 & 99938 & 91,3 \\
\hline Opolskie & 28238 & 3,3 & 5521 & 19,6 & 22717 & 80,4 \\
\hline Podkarpackie & 70693 & 8,2 & 18311 & 25,9 & 52382 & 74,1 \\
\hline Podlaskie & 42589 & 5,0 & 7410 & 17,4 & 35179 & 82,6 \\
\hline Pomorskie & 38635 & 4,5 & 8762 & 22,7 & 29873 & 77,3 \\
\hline Śląskie & 23367 & 2,7 & 2278 & 9,7 & 21089 & 90,3 \\
\hline Świętokrzyskie & 45815 & 5,3 & 8183 & 17,9 & 37632 & 82,1 \\
\hline Warmińsko-mazurskie & 43531 & 5,1 & 17880 & 41,1 & 25651 & 58,9 \\
\hline Wielkopolskie & 61252 & 7,1 & 7146 & 11,7 & 54106 & 88,3 \\
\hline Zachodniopomorskie & 45147 & 5,3 & 17204 & 38,1 & 27943 & 61,9 \\
\hline Polska ogółem & 856982 & 100,0 & 155442 & 18,1 & 701540 & 81,9 \\
\hline
\end{tabular}

Źródło: Opracowanie własne na podstawie Kałkowski [2011, 2015].

${ }^{5}$ Dz.U. 2016, poz. 585 z późn. zm. 
tów sprzedanych w 2016 roku wynosiła zaledwie 17708 ha, wobec 76700 ha w 2015 roku i 120600 ha w 2014 roku [Biuletyn 2017].

Analiza danych udostępnianych od 2003 roku przez Główny Urząd Statystyczny wskazuje na dynamiczny wzrost wartości transakcji sprzedaży nieruchomości rolnych, co w głównej mierze jest wynikiem wzrostu ich cen jednostkowych [Załęczna 2016]. Ceny te uzależnione są od wielu czynników, wśród których coraz większe znaczenie ma tzw. renta położenia. Decyduje ona o zainteresowaniu gruntami rolnymi ze strony ,inwestorów zewnętrznych”, co wiąże się z ich konwersją na inne cele. Rentę położenia można zdefiniować jako swego rodzaju premię przejawiającej się na różne sposoby atrakcyjnej lokalizacji. Stanowi ona pewien potencjał, który w porę dostrzeżony i odpowiednio wykorzystany może przynieść mniej lub bardziej wymierne korzyści [Ossowska 2012].

Rozwój cywilizacyjny powoduje stopniowe zacieranie się granic między miastem a wsią, co jest szczególnie widoczne na obrzeżach dużych aglomeracji miejskich [Scorson 2004]. Prowadzone analizy wskazują na kształtowanie się w strefach podmiejskich specyficznego dla nich rynku gruntów rolnych. Biorąc pod uwagę różnice w poziomie cen rynkowych, można dokonać jego podziału na trzy zasadnicze segmenty: gruntów nabywanych dla potrzeb prowadzenia działalności rolniczej, gruntów postrzeganych jako potencjalne grunty budowlane oraz gruntów o wysokich walorach przyrodniczych, nabywanych dla potrzeb rekreacyjnych [Krajewska 2011].

Obrazu polskiego rynku nieruchomości rolnych dopełniają transakcje pozarynkowe, dokonywane bez użycia pieniędzy, do których zalicza się darowizny, spadki i umowy zbycia, głównie gospodarstw rolnych, za wypłatę świadczeń z ubezpieczenia społecznego. W latach 2004-2013 stanowiły one łącznie 45,3\% transakcji ogółem, przy czym największa ich część przypada na województwa: mazowieckie, lubelskie, podkarpackie i małopolskie (tab. 3).

$\mathrm{Z}$ analizy struktury pozarynkowych transakcji nieruchomościami rolnymi wynika, że w latach 2004-2013 zdecydowanie największą ich część stanowiły darowizny (77,6\%), których udział w porównaniu $\mathrm{z}$ analogicznym okresem lat 1994-2003 wzrósł o 21,5 p.p. Na drugim miejscu plasowały się umowy zbycia nieruchomości za uzyskanie świadczenia z ubezpieczenia społecznego $(11,5 \%)$, a pozostałą część stanowiły działy spadku i zniesienie współwłasności $(8,0 \%)$ oraz umowy o dożywocie $(2,9 \%)$.

Transakcje pozarynkowe trwale związane z zasobami nieruchomości podlegaja procesom demograficznym i historycznie uwarunkowanym zwyczajom społecznym [Kałkowski i Karaś 2016]. W ujęciu dynamicznym widoczny jest systematyczny spadek ich udziału w transakcjach nieruchomościami rolnymi ogólem. Na początku polskiej transformacji ustrojowej kształtował się on na poziomie ponad 70\%, w 1994 roku było to 59\%, a w 2004 roku odpowiednio 51\% 
Tabela 3

Polski rynek nieruchomości rolnych według województw - transakcje pozarynkowe (dane skumulowane za lata 2004-2013)

\begin{tabular}{|c|c|c|c|c|c|c|}
\hline \multirow{4}{*}{ Województwa } & \multicolumn{6}{|c|}{ Transakcje pozarynkowe } \\
\hline & \multicolumn{2}{|c|}{ razem } & \multicolumn{4}{|c|}{ w tym } \\
\hline & \multirow{2}{*}{ liczba } & \multirow{2}{*}{$\begin{array}{c}\%] \\
\text { (Polska } \\
=100)\end{array}$} & \multicolumn{2}{|c|}{ darowizny } & \multicolumn{2}{|c|}{ inne } \\
\hline & & & liczba & [\%] & liczba & [\%] \\
\hline Dolnośląskie & 23859 & 3,7 & 19682 & 82,5 & 4177 & 17,5 \\
\hline Kujawsko-pomorskie & 28097 & 4,0 & 19812 & 70,5 & 8285 & 29,5 \\
\hline Lubelskie & 96099 & 13,6 & 75918 & 79,0 & 20181 & 21,0 \\
\hline Lubuskie & 7767 & 1,1 & 6784 & 87,3 & 983 & 12,7 \\
\hline Łódzkie & 52854 & 7,5 & 39161 & 74,1 & 13693 & 25,9 \\
\hline Małopolskie & 77330 & 10,9 & 56606 & 73,2 & 20724 & 26,8 \\
\hline Mazowieckie & 102338 & 14,4 & 79381 & 77,6 & 22957 & 22,4 \\
\hline Opolskie & 16183 & 2,3 & 11769 & 72,7 & 4414 & 27,3 \\
\hline Podkarpackie & 85746 & 12,1 & 72054 & 84,0 & 13692 & 16,0 \\
\hline Podlaskie & 41611 & 5,9 & 30416 & 73,1 & 11195 & 26,0 \\
\hline Pomorskie & 19413 & 2,7 & 15351 & 79,1 & 4062 & 20,9 \\
\hline Śląskie & 24640 & 3,5 & 19936 & 80,9 & 4704 & 19,1 \\
\hline Świętokrzyskie & 54069 & 7,6 & 43390 & 80,2 & 10679 & 19,8 \\
\hline Warmińsko-mazurskie & 17326 & 2,4 & 14177 & 81,8 & 3149 & 18,2 \\
\hline Wielkopolskie & 44748 & 6,3 & 31486 & 70,4 & 13262 & 29,6 \\
\hline Zachodniopomorskie & 16264 & 2,3 & 13706 & 84,3 & 2558 & 15,7 \\
\hline Polska ogółem & 708344 & 100,0 & 549629 & 77,6 & 158715 & 22,4 \\
\hline
\end{tabular}

Źródło: Opracowanie własne na podstawie Kałkowski [2011, 2015].

[Kałkowski 2011]. W 2013 roku zrealizowane w skali kraju transakcje pozarynkowe stanowiły łącznie niewiele ponad $40 \%$ ogółu transakcji nieruchomościami rolnymi. Najmniej tego typu transakcji realizowano niezmiennie na terenie województw: lubuskiego, opolskiego i zachodniopomorskiego [Kałkowski 2015].

\section{Regionalne zróżnicowanie zjawiska nabywania nieruchomości rolnych przez cudzoziemców}

W Polsce obowiązuje zasada, że aby nabyć nieruchomość obywatele innych państw muszą uzyskać stosowne zewzwolenie, co reguluje ustawa z 24 marca 1920 roku o nabywaniu nieruchomości przez cudzoziemców ${ }^{6}$. Mimo że w przy-

${ }^{6}$ Dz.U. 2016, poz. 1061 z późn. zm. 
wołanej ustawie używane jest pojęcie nieruchomości rolnej, termin ten nie został w niej zdefiniowany. Brak takiej definicji, przy rozbieżnościach w definiowaniu tego pojęcia $w$ innych aktach prawnych, skutkował wieloma problemami natury praktycznej związanymi z kwalifikowaniem konkretnej nieruchomości jako rolnej. Miało to m.in. znaczenie dla określenia, czy w ramach zainicjowanej przez cudzoziemca sprawy administracyjnej właściwy minister do spraw rolnictwa i rozwoju wsi mógł wnieść sprzeciw wobec nabycia przez niego tego rodzaju nieruchomości. Problemów interpretacyjnych doświadczały również sądy powszechne w ramach dokonywanej przez nie oceny ważności zakwestionowanych transakcji [Sęczkowski 2017].

Obowiązująca obecnie ustawa o nabywaniu nieruchomości przez cudzoziemców była wielokrotnie nowelizowana. Najistotniejsza co do skutków prawnych zmiana podyktowana była koniecznością dostosowania polskiego prawa do prawa Unii Europejskiej i wynikających z niego podstawowych zasad wspólnotowego rynku wewnętrznego, w tym zasady swobody przepływu kapitału obejmującej również inwestycje w nieruchomości. Z dniem 1 maja 2004 roku usunięto ograniczenia dotyczące nabywania nieruchomości przez obywateli i przedsiębiorców Europejskiego Obszaru Gospodarczego. Wyjątek stanowiły nieruchomości rolne i leśne, do których miał zastosowanie wynegocjowany dwunastoletniletni okres przejściowy.

Jak wynika ze sprawozdań Ministerstwa Spraw Wewnętrznych i Administracji w latach 2004-2013 cudzoziemcy nabyli na podstawie zezwoleń i bez konieczności ich uzyskania grunty o powierzchni nieprzekraczającej $0,2 \%$ powierzchni ogólnej kraju [Klusek 2016], z czego grunty rolne stanowiły niewiele ponad $10 \%$. $Z$ analizy struktury nabytej powierzchni można wnioskować, że największym ich zainteresowaniem cieszyły się nieruchomości zlokalizowane na terenie województw wielkopolskiego, dolnośląskiego i mazowieckiego. Znacznie mniej atrakcyjne były dla nich inne lokalizacje, w województwach podlaskim i podkarpackim (tab. 4).

W związku z zagrożeniem, że po upływie okresu przejściowego ziemia rolna $\mathrm{w}$ Polsce będzie przedmiotem wzmożonego zainteresowania nabywców z innych krajów Unii Europejskiej, uchwalono ustawę z dnia 14 kwietnia 2016 roku o wstrzymaniu sprzedaży nieruchomości Zasobu Własności Rolnej Skarbu Państwa oraz o zmianie niektórych ustaw. Dokonała ona licznych zmian w treści obowiązującej obecnie ustawy o kształtowaniu ustroju rolnego ${ }^{7}$ regulującej obrót nieruchomościami rolnymi stanowiącymi własność prywatną oraz ustawy

\footnotetext{
${ }^{7}$ Ustawa z dnia 11 kwietnia 2003 roku o kształtowaniu ustroju rolnego, Dz.U. z 2016, poz. 2052 z późn. zm.
} 
Tabela 4

Nieruchomości rolne nabyte przez cudzoziemców według województw (dane skumulowane za lata 2004-2013)

\begin{tabular}{|c|c|c|c|c|}
\hline \multirow{4}{*}{ Województwa } & \multicolumn{4}{|c|}{ Powierzchnia nabytych przez cudzoziemców gruntów rolnych } \\
\hline & \multirow{3}{*}{ w ha } & \multicolumn{3}{|c|}{$\mathrm{w}[\%]$} \\
\hline & & \multicolumn{2}{|c|}{$\begin{array}{c}\text { nabytej powierzchni } \\
\text { nieruchomości }\end{array}$} & \multirow{2}{*}{ Polska $=100$} \\
\hline & & gruntowych & $\begin{array}{c}\text { rolnych } \\
\text { i leśnych }\end{array}$ & \\
\hline Dolnośląskie & 387,56 & 8,2 & 95,7 & 10,0 \\
\hline Kujawsko-pomorskie & 135,62 & 11,9 & 96,8 & 3,5 \\
\hline Lubelskie & 151,15 & 17,4 & 96,3 & 3,9 \\
\hline Lubuskie & 313,36 & 16,7 & 98,6 & 8,1 \\
\hline Łódzkie & 261,53 & 8,5 & 85,5 & 6,7 \\
\hline Małopolskie & 199,79 & 11,8 & 92,0 & 5,2 \\
\hline Mazowieckie & 352,98 & 6,0 & 82,8 & 9,1 \\
\hline Opolskie & 204,48 & 11,0 & 98,5 & 5,3 \\
\hline Podkarpackie & 102,18 & 12,7 & 80,6 & 2,6 \\
\hline Podlaskie & 105,89 & 20,2 & 95,1 & 2,7 \\
\hline Pomorskie & 225,72 & 12,4 & 98,7 & 5,8 \\
\hline Śląskie & 235,84 & 4,7 & 67,9 & 6,1 \\
\hline Świętokrzyskie & 249,57 & 27,5 & 91,4 & 6,4 \\
\hline Warmińsko-mazurskie & 190,97 & 13,3 & 89,4 & 4,9 \\
\hline Wielkopolskie & 500,05 & 14,3 & 96,3 & 12,9 \\
\hline Zachodniopomorskie & 265,32 & 13,3 & 96,4 & 6,8 \\
\hline Polska ogółem & 3881,64 & 10,5 & 90,9 & 100 \\
\hline
\end{tabular}

Źródło: Opracowanie własne na podstawie Sprawozdań Ministra Spraw Wewnętrznych i Administracji z realizacji ustawy z 24 marca 1920 roku o nabywaniu nieruchomości przez cudzoziemców za lata 2004-2014.

o gospodarowaniu nieruchomościami rolnymi skarbu państwa ${ }^{8}$ odnoszącej się do obrotu gruntami państwowymi.

Nowo wprowadzone regulacje wpisują się w rozwiązania, jakie w zakresie kontroli obrotu gruntami rolnymi funkcjonują w prawodawstwie innych krajów Unii Europejskiej. W przypadku tzw. starych krajów wspólnoty różnego rodzaju ograniczenia w tym zakresie stosują m.in. Francja, Niemcy czy Dania. Z „nowych" krajów członkowskich jako pierwszy ustawę o obrocie gruntami rolnymi

\footnotetext{
${ }^{8}$ Ustawa z dnia 19 października 1991 roku o gospodarowaniu nieruchomościami rolnymi Skarbu Państwa, Dz.U. z 2016, poz. 1491 z późn. zm.
} 
uchwalił parlament Węgier, warunkując ich nabycie posiadaniem kwalifikacji rolniczych lub prowadzeniem na terenie tego kraju udokumentowanej działalności rolniczej [Stankiewicz 2015].

\section{Podsumowanie}

Polski rynek nieruchomości rolnych charakteryzuje się dużym zróżnicowaniem regionalnym, czego wyrazem jest udział poszczególnych rynków wojewódzkich $\mathrm{w}$ transakcjach rozpatrywanych zarówno w ujęciu ogólnym, jak i w podziale na transakcje rynkowe i pozarynkowe. Największą aktywnością w tym zakresie charakteryzują się województwa lubelskie, mazowieckie i podkarpackie. W latach 2004-2013 transakcje gruntami rolnymi stanowiły około $1 / 4$ obrotów na rynku nieruchomości w kraju, przy czym udział ten wykazuje stałą tendencję spadkową.

Na rozmiary i strukturę transakcji wpływa wiele czynników, z których większość ma charakter makroekonomiczny i stanowi element prowadzonej przez państwo polityki rolnej. W tym kontekście zasoby gruntów rolnych i ich rozdysponowanie, zarówno na rynku prywatnym, jak i państwowym, stanowią jeden z kluczowych elementów programu restrukturyzacji polskiego rolnictwa i jego dostosowywania do wymogów konkurencyjnego rynku europejskiego.

Na rozwój polskiego rynku nieruchomości rolnych ograniczony wpływ mają inwestorzy zagraniczni, co wiąże się z reglamentacją transakcji realizowanych z ich udziałem, wynikającą z ustawy z dnia 24 marca 1920 roku o nabywaniu nieruchomości przez cudzoziemców. W latach 2004-2013 nabyli oni łącznie w sposób bezpośredni ponad 3880 ha, co stanowi zaledwie 10\% nabytych przez cuzoziemców nieruchomości gruntowych. Największym ich zainteresowaniem, biorąc pod uwagę kryterium powierzchniowe, cieszyły się grunty rolne zlokalizowane na terenie województw wielkopolskiego, dolnośląskiego i mazowieckiego. Skala tego zjawiska była natomiast znacznie mniejsza w przypadku takich województw jak podlaskie czy podkarpackie.

W kontekście przepisów wymienionej ustawy w przypadku nabywania nieruchomości rolnych przez cudzoziemców zastosowanie mają regulacje zawarte w ustawie $\mathrm{z}$ dnia 11 kwietnia 2003 roku o kształtowaniu ustroju rolnego. Ich nowelizacja w drodze ustawy z dnia 14 kwietnia 2016 roku o wstrzymaniu sprzedaży nieruchomości Zasobu Własności Rolnej Skarbu Państwa oraz zmianie niektórych ustaw, w istotny sposób ograniczyła możliwości obrotu tego typu nieruchomościami, co dotyczy wszystkich nabywców bez względu na obywatelstwo czy kraj pochodzenia. Wprowadzone zmiany ze względu na ich zakres były i nadal pozostają tematem licznych publikacji, analiz i wypowiedzi przedstawi- 
cieli różnych środowisk, w tym specjalistów z zakresu prawa rolnego, rolników i zrzeszających ich organizacji. Z perspektywy krótkiego czasu, jaki upłynął od wejścia $\mathrm{w}$ życie nowych przepisów, trudno w sposób jednoznaczny szacować ich skutki. Szczegółowa, a co się z tym wiąże bardziej wiarygodna ocena, będzie możliwa dopiero w dłuższej perspektywie.

\section{Literatura}

BELNIAK S., UCHMAN R. 2001: Rynek nieruchomości gruntowych w Polsce, Świat Nieruchomości 32, 17-21.

Biuletyn Informacyjny, 7-8 (2017), MRiRW, Warszawa, 22-25.

BRYX M., 2000: Rynek nieruchomości w Polsce i jego przeksztatcenia, [w:] Uwarunkowania rozwoju rynku nieruchomości w Polsce, IFGN SGH, Warszawa, 11-29.

BRYX M. 2006: Rynek nieruchomości system i funkcjonowanie, Poltext, Warszawa.

CELLMER R., 1999: Zasady i metody analizy elementów składowych rynku nieruchomości, Educaterra, Olsztyn.

CYMERMAN R. (red.), 2011: Podstawy rolnictwa $i$ wycena nieruchomości rolnych, Educaterra, Olsztyn.

CZECHOWSKI P. (red.), 2015: Prawo rolne 3, Wolters Kluwer, Warszawa.

CZERWIŃSKA-KORAL K., 2016: Pojęcia niedookreślone $w$ przepisach ustawy o ksztattowaniu ustroju rolnego, Temida 2, Studia Iuridica Agraria 14, 191-206.

HOPFER A., 1997: Szacowanie nieruchomości niezurbanizowanych 3, Twigger, Warszawa.

KAŁKOWSKI L. (red.), 2011: Monitoring polskiego rynku nieruchomości - raport za 2009 rok, Instytut Rozwoju Miast, Kraków.

KAŁKOWSKI L. (red.), 2015: 25 lat polskiego rynku nieruchomości - monitoring za lata 1990-2014, Instytut Rozwoju Miast, Kraków.

KAŁKOWSKI L., KARAŚ Ł., 2016: Pozarynkowe transakcje nieruchomościami w Polsce $w$ latach 2003-2013 - ujęcie prawne i podatkowe, Zeszyty Naukowe Małopolskiej Wyższej Szkoły Ekonomicznej w Tarnowie 2 (30), 13-26.

KAŁKOWSKI L, RYDZIK W. 2008: Poszerza się wiedza o polskim rynku nieruchomości, Świat Nieruchomości 3 (65), 16-21.

KLANK L., 2006 : Sukcesja gospodarstw rolnych w Polsce, IRWiR PAN, Warszawa

KLUSEK T., 2014: Uwarunkowania $i$ skala wytaczania na cele nierolnicze gruntów o największej przydatności produkcyjnej, Roczniki Naukowe Stowarzyszenia Ekonomistów Rolnictwa i Agrobiznesu 16 (6), 235-240.

KLUSEK T., 2016: Inwestorzy zagraniczni na polskim rynku nieruchomości, Zeszyty Naukowe Szkoły Głównej Gospodarstwa Wiejskiego w Warszawie. Problemy Rolnictwa Światowego 16 (31), 167-180.

KOWALSKI A., (red.), 2015: Analiza produkcyjno-ekonomicznej sytuacji rolnictwa i gospodarki żywnościowej, Instytut Ekonomiki Rolnictwa i Gospodarki żywnościowej, Warszawa. 
KRAJEWSKA M., 2011: Ksztaltowanie się wartości gruntów w strefie podmiejskiej miasta Bydgoszczy, [w:] H. Gawron (red.), Stan i tendencje rozwoju rynku nieruchomości, Zeszyty Naukowe 192, Wydawnictwo Uniwersytetu Ekonomicznego w Poznaniu, 70-80.

KRZYK P., TOKARCZUK T., HECZKO-HYŁOWA E., ZIOBROWSKI Z., 2013: Obszary rolne jako element struktury przestrzennej miast - problemy planistyczne, Instytut Rozwoju Miast, Kraków.

KUCHARSKA-STASIAK E., (red.), 2001: Bariery rozwoju rynku nieruchomości, Oficyna Wydawnicza Branta, Łódź.

KUCHARSKA-STASIAK E. 2006: Nieruchomość w gospodarce rynkowej, Wydawnictwo Naukowe PWN, Warszawa.

OSSOWSKA L., 2012: Renta położenia jako determinanta rozwoju spoleczno-gospodarczego obszarów wiejskich w Polsce, Wydawnictwo Uniwersytetu Przyrodniczego w Poznaniu.

OSTROWSKI L., 1996: Rynek ziemi rolniczej w latach 1991-1995, Studia i Monografie 79, Instytut Ekonomiki Rolnictwa i Gospodarki Żywnościowej, Warszawa.

OSTROWSKI L., 1998.: Rynek ziemi rolniczej stan i perspektywy, Instytut Ekonomiki Rolnictwa i Gospodarki Żywnościowej, Warszawa.

PRZEWIĘŹLIKOWSKA A., 2016: Transformacja mienia Skarbu Państwa w kontekście aktualnych przepisów prawa, Infrastruktura i Ekologia Terenów Wiejskich 2 (1), 423-443.

SCORSON E.A., 2004: Rural Development and Urban Sprawl: Convergening Interests or Opposing Sides ?, Rural Development Center 7, 1.

SĘCZKOWSKI D., 2017: Nabywanie nieruchomości rolnych przez cudzoziemców, [w:] P. Księżak, J. Mikołajczyk (red.), Nieruchomości rolne w praktyce notarialnej, Wolters Kluwer, Warszawa, 283-305.

SIEMIŃSKA E., 2006: Ryzyko na rynku nieruchomości - wybrane problemy, [w:] A. Nalepka (red.), Inwestycje $i$ nierychomości, Wydawnictwo Akademii Ekonomicznej w Krakowie, Kraków, 131-147.

Sprawozdania Ministra Spraw Wewnętrznych i Administracji z realizacji ustawy z dnia 24 marca 1929 roku o nabywaniu nieruchomości przez cudzoziemców za lata 2004-2014, MSWiA, Warszawa.

STANKIEWICZ D., 2015: Nabywanie ziemi rolniczej przez cudzoziemców w Polsce, BAS, 7 (190), Warszawa.

TRUSZKIEWICZ Z., 2017: Zakres stosowania ustawy o ksztattowaniu ustroju rolnego po nowelizacji z 2016 r., Rejent 7 (315), 95-124.

Ustawa z dnia 24 marca 1920 roku o nabywaniu nieruchomości przez cudzoziemców, Dz.U. z 2016, poz. 1061 z późn. zm.

Ustawa z dnia 19 października 1991 roku o gospodarowaniu nieruchomościami rolnymi Skarbu Państwa, Dz.U. z 2016, poz. 1491 z późn. zm.

Ustawa z dnia 11 kwietnia 2003 roku o ksztaltowaniu ustroju rolnego, Dz.U. z 2016, poz. 2052 z późn. zm.

Ustawa z dnia 14 kwietnia 2016 roku o wstrzymaniu sprzedaży nieruchomości Zasobu Własności Rolnej Skarbu Państwa oraz zmianie niektórych ustaw, Dz.U. z 2016, poz. 585 z późn. zm. 
WOŚ A (red.), 2007: Analiza produkcyjno-ekonomicznej sytuacji rolnictwa i gospodarki żywnościowej w 2006 roku, Instytut Ekonomiki Rolnictwa i Gospodarki Żywnościowej, Państwowy Instytut Badawczy, Warszawa.

ZAŁĘCZNA M., 2010: Instytucjonalne uwarunkowania rozwoju rynku nieruchomości w Polsce na tle doświadczeń państw zachodnich, Wydawnictwo Uniwersytetu Łódzkiego, Łódź.

ZAŁĘCZNA M. 2016: Inwestowanie w nieruchomości rolne - Polska na tle wybranych państw, Świat Nieruchomości 96, 27-35.

ŻELAZOWSKI K., 2014: Regionalne zróżnicowanie cen gruntów rolnych w Polsce, Zeszyty Naukowe Uniwersytetu Szczecińskiego, Studia i Prace Wydziału Nauk Ekonomicznych i Zarządzania 36, 531-542.

\section{Abstrakt}

Rynek nieruchomości nie jest rynkiem jednolitym, w związku z tym, w zależności od przyjętych kryteriów, można dokonać jego podziału na różne segment. Do najczęściej stosowanych kryteriów klasyfikacji tego rynku, dla potrzeb prowadzonych analiz, zaliczyć należy kryterium przedmiotowe. Uwzględnia ono funkcje pełnione przez nieruchomości, a jednym z segmentów wyodrębnianych na jego podstawie jest rynek nieruchomości rolnych.

Dane dotyczące obrotu nieruchomościami rolnymi w skali kraju i poszczególnych województw mogą być wykorzystane dla różnych celów, w szczególności dla potrzeb wyznaczania kierunków przekształceń strukturalnych w rolnictwie. W tym kontekście istotne jest poznanie uwarunkowań tego zjawiska, jego natężenia oraz struktury, co jest przedmiotem niniejszego opracowania.

Slowa kluczowe: rynek nieruchomości, nieruchomości rolne, województwa

\section{Size and Regional Differences in the Polish Agricultural Property Market}

\section{Abstract}

The property market is not a unite market and therefore depending on employed criteria can be divided into various segments. In order to provide an analysis the objective criterion is most often used. It reflects functions of particular properties and on such basis the segment of agricultural properties can be distinguished.

The data on agricultural property sales in the whole country scale as well as in provinces can be employed for various purposes, particularly for defining of 
structural changes in agriculture. In order to do so it is necessary to recognise the background of the property sales, their scope and structure which is the topic of the paper.

Key words: property market, agricultural properties, provinces 